\title{
Determinants of cross-border mergers and acquisitions in the freight and logistics industry of South Africa
}

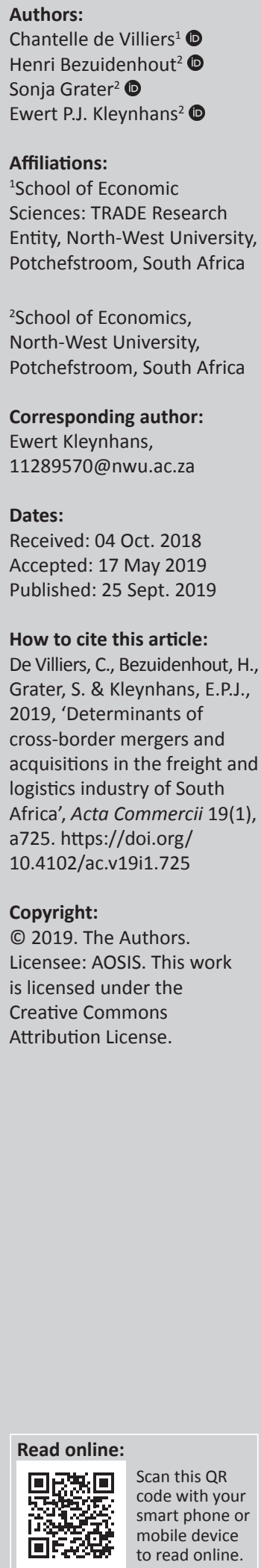

Orientation: The article reports on applied and practical research that focuses on the understanding of the motivation and actions of Multinational Enterprises in Africa as far as mergers and acquisitions (M\&As) are concerned.

Research purpose: This study examines developments in the freight and logistics industry through M\&As in South Africa.

Motivation for the study: It is necessary to gain a better understanding of M\&As from a firmlevel perspective in the South African context. Little research exists on the dynamics of M\&As, and even less relating to the logistics industry that plays such a large role in trade in the region. This research adds substantial and significant original work to the scarce body of meaningful literature on foreign direct investment (FDI) in Africa.

Research design, approach and method: This study used a case study approach employing structured interviews. The population was freight and logistics companies that were involved in M\&A activities in South Africa. Quantitative data and other information from various databases, published M\&A data and financial statements were analysed to obtain background views of the companies' where after, three companies were eventually selected. Direct unstructured interviews were then conducted with the main decision makers and a qualitative thematic analysis of the companies' responses. Related themes and patterns were identified through the frequency of occurrence, similarities, differences and general patterns observed. This method yielded the most insight into the processes and company dynamics involved.

Main findings: International M\&As in the freight and logistics industry provide companies with international scale and effectively link to international markets. Companies benefit from expanded market opportunities across national borders, which generate substantial revenues, geographical growth and business expansion. It renders synergy and additional competitive advantage.

Practical/managerial implications: Theoretical and practical aspects of FDI, such as motives for market entry, ownership, location and entry barriers within the context of multinational enterprises, globally, were investigated. Little data exist on the freight and logistics industry in Africa and also on M\&As, which presented limitations. Companies are inexperienced and need to involve more expertise in M\&A processes. The results also found that South African companies need to expand their cultural intelligence and negotiation skills, especially within a diverse cultural realm, before entering into M\&A deals with foreign companies.

Contribution/value-add: Services are determinants of trade volumes and offer distributional effects and patterns of economic growth, development and FDI inflows. Little research exists on the dynamics of M\&As in the freight and logistics industry, especially within the African context. This study also makes some contribution in that regard.

Keywords: foreign direct investment; merger; acquisition; services; freight and logistics; inorganic growth; industries; multinational enterprise.

\section{Introduction}

Mergers and acquisitions (M\&As) are driving a large portion of foreign direct investment (FDI) (Erel, Liao \& Weisbach 2012). This applies to FDI inflows both globally and in developing and emerging economies such as South Africa. Foreign direct investment not only drives productivity, technological progress and growth in employment levels but also fills the gaps that exist in emerging and developing countries with regard to development, local investment, foreign exchange and tax revenues (Quazi 2007; Rahim et al. 2013; Smith 1997). This study, therefore, investigates the driving forces behind the M\&A activities of foreign companies in the freight and logistics industry of South Africa, and why multinational enterprises (MNEs) focus on this kind of investment and expansion. 
Foreign direct investment is described as a transfer of factors complementary to capital and transfer of ownership. Foreign direct investment is growing faster than world production and trade in both emerging and developed countries. A country needs capital for its economy to grow, and FDI is one of the most valuable forms of capital for developing countries. The African continent consists of both developing and emerging economies, as well as some least-developed countries, and FDI forms an integral part of supporting their efforts to grow and develop (Anyanwu 2006; Deng \& Yang 2015; Dupasquier \& Osakwe 2003).

Within the international trade sector, the global freight and logistics industry specifically serves as a direct beneficiary of globalisation and has been growing at a fast pace, generating high amounts of returns on capital, thereby attracting both strategic and financial investors. Due to steep competition in this industry, companies try to minimise their financial risks, reduce costs, create significant economies of scale and rationalise their activities (Bezuidenhout \& Kleynhans 2018; Meersman \& Van de Voorde 1999).

The freight and logistics industry is also highly capitalintensive, and some companies lean towards inorganic growth methods such as M\&As to retain a competitive advantage or grow their global footprint (Samitas \& Kenourgios 2007). Organic growth refers to ordinary growth, where a business grows through strong management and effective planning. Growth through unorthodox methods, such as M\&As, is regarded as inorganic. Companies usually grow faster through inorganic methods and provide faster access to new markets and distribution channels (Das \& Kapil 2015). It seems that these investors are operating on the notion that 'bigger is better', and consequently the world is seeing an upsurge in the number of M\&As in this industry.

This article therefore aims to investigate drivers behind the cross-border M\&As in the freight and logistics industry of South Africa. The main goal was to attain an understanding of the determinants of cross-border M\&As in South Africa. The methodology follows a mixed methods approach, studying the hard data and then focusing on specific case studies. The results will be of special value to policymakers and managers of South African freight and logistics companies, providing insight into making informed strategic planning decisions regarding inorganic expansion through M\&As.

The following section discusses the relevant literature on the role that FDI, through M\&As, has played in the freight and logistics industry.

\section{Literature on foreign direct investment and mergers and acquisitions \\ Motives of foreign investments - Some theoretical perspectives}

The driving forces as to why MNEs often pursue FDI activities are usually linked to their long-term strategic and financial goals, which focus on cost reduction and growth (Dhliwayo 2017; Masipa 2018). Taking the economic environment into account, MNEs might have to depend on inorganic growth methods, as organic growth methods might not be sufficient to reach their aggressive growth targets (Das \& Kapil 2015).

The ownership, location and internalisation (OLI) theory includes three approaches that may prove advantageous for an MNE considering engaging in FDI activities abroad (Hurst 2011). This theory explores reasons why companies invest abroad and especially why companies would use FDI when internationalising as opposed to other modes of entry. According to Dunning and Lundan (2008a), MNEs are attracted to FDI activities abroad when substantial advantages are available (Shimizu et al. 2004).

Although other theories might exist, the OLI offered the most rigid theoretical foundation for the intended current investigation. The OLI theory is a context-specific theory with a holistic approach to analyse the MNEs' level and structure of FDI (Bezuidenhout, Grater \& Kleynhans 2018). 'Ownership' addresses the issue of some companies going abroad while others do not, and also discusses the companyspecific benefits that help an MNE diminish the high foreign operating cost (Coetzee et al. 2016). 'Location' places emphasis on the chosen geographical location (Malhotra \& Hinings 2010). Choosing a specific location might be affected by the exploitation of specific assets in a foreign country or benefiting from the cheaper labour and production facilities in a foreign country. 'Internalisation' inspires the operating structure that an MNE will follow when operating abroad (Dunning 1977, 2001).

Foreign direct investment further consists of four categories: resource-seeking FDI, market-seeking FDI, efficiencyseeking FDI and strategic-asset-seeking FDI (Bezuidenhout \& Kleynhans 2018). Resource-seeking FDI comprises MNEs seeking high value goods and/or services, such as various production inputs and natural resources, at lower costs abroad compared to that in their home country. The objective of market-seeking FDI is to find suitable and attractive markets to distribute and sell products and/or services (Dunning \& Lundan 2008b). If an MNE's main goal is to improve its efficiency in terms of productivity enhancement and cost reduction, it follows what is known as efficiency-seeking FDI behaviour (Narayan \& Thenmozhi 2014), whereas MNEs seeking to grow their competitive ranking on a global scale are known as strategic-asset-seeking FDI (Tao et al. 2017).

Increased investment is usually subject to diminishing returns according to the neo-classical literature (Mankiw 2014). Endogenous growth theories, on the other hand, state that long-term growth can be achieved if positive spill-overs (indirect effects) from FDI result in diminishing returns (Kleynhans \& Zwedala 2012). Economic geography also supports the idea of positive spill-overs resulting due to the 
formation of agglomerations. It suggests that it can be one of the most important determinants of FDI location. By internalising investment through FDI, a company can reduce the market imperfections, which will, in turn, result in more efficient transactions (Changqi \& Ningling 2010).

As FDI has presented many markets and companies with invaluable contributions to their growth and development strategies, countries have started to compete in acquiring more FDI over the past decade (Masipa 2018). These higher levels of competition for FDI, to achieve higher growth rates and reduce poverty levels, have led to the liberalisation of trade barriers and restrictions. The liberalisation of trade and general policies has led to better competitiveness and trade situations, as well as better-quality investment climates.

A comprehensive understanding of FDI provides a framework for this article. The next section considers the role of FDI specifically through M\&As in the freight and logistics industry.

\section{The role of mergers and acquisitions in strategy and management}

Continuing a competitive position in markets under changing economic conditions has drawn companies to utilise inorganic growth approaches such as M\&As when organic growth methods are not sufficient. A large portion of FDI is through M\&As (Bertrand 2004; Erel et al. 2012). Trade liberalisation is progressing globally, leading to economic integration where investment and trade barriers are declining. This then facilitates the possibility of global expansion through easier M\&As. MNEs have also experienced global restructuring, improved performance and have met financial targets through M\&As (Deng \& Yang 2015).

A company's business organisational and corporate strategy can benefit from M\&As (Tao et al. 2017; Rappaport 1986). For a company to gain more market advantage, it needs to create shareholder value (Rappaport 1998). Many assume that a large company is much more valuable than two separate companies, which motivates M\&As to play a prominent role in modern business economies (Harding et al. 2012; Yang 2015).

Mergers and acquisitions deal with aspects such as corporate finance, corporate strategy and management, focusing their attention on buying, selling and/or combining different companies to help a company grow and be more competitive in a certain industry without having to create another business entity (Kimura 1998; Shimizu et al. 2004). These two words are more often than not used together as one term, where, in fact, they do have quite distinct meanings. A merger is an amalgamation of companies, while in an acquisition one company takes over the other. In a merger, the identities of both companies continue jointly in the new, while in acquisitions, the one company is totally dissolved and absorbed by the other. During an acquisition, the controlling company keeps its name and legal identity (Jurevicius 2013).

\section{Common motives behind mergers and acquisitions}

According to researchers, such as Dier et al. (2012), and Moeller and Brady (2007), M\&As take place because of various reasons. The reasons why M\&As take place vary from deal to deal and depend on the short- and long-term objectives of a company. Some of the most commonly identified motives for M\&As are provided in Figure 1. Whether all of these motives are really prevalent or correct might be questioned, which also forms part of the rationale of the current study. These motives are also further discussed in the sections following.

Foreign direct investment through M\&As can have a positive influence on company growth and maintains competitive advantage in the relevant sector in which it operates (AsafoAdjei 2007; Masipa 2018). It can provide access to new markets, new technology and cheaper production facilities (Buono 1997; Changqi \& Ningling 2010), as well as a wider range of products, marketing channels and finance options (Sun 2002). The same progressive influences can be gained by both companies involved (Dhliwayo 2017; Sun 2002). It also offers stimuli for economic growth and global trade expansions, which are desirable for both the host and target countries (Fortanier 2007; Masipa 2018). There are also other reasons why companies turn to M\&As as trade expansions (Malhotra \& Hinings).

Newburry and Zeira (1997) and Yang (2015) state that, as a general rule, companies turn to M\&As to exploit synergies between rival operators and markets, capture economies of scale in production, and increase management efficiencies. Alternative to internally generated corporate growth, inorganic growth methods such as M\&As are a prevalent form of corporate development and one of the best sources of FDI (Cartwright \& Schoenberg 2006; Masipa 2018). This has been especially evident in the number of recorded M\&As in the freight and logistics industry since the commencement of the third millennium (Dhliwayo 2017; Dier et al. 2012). These transactions highlight freight and logistics companies' view of the inorganic growth approach.

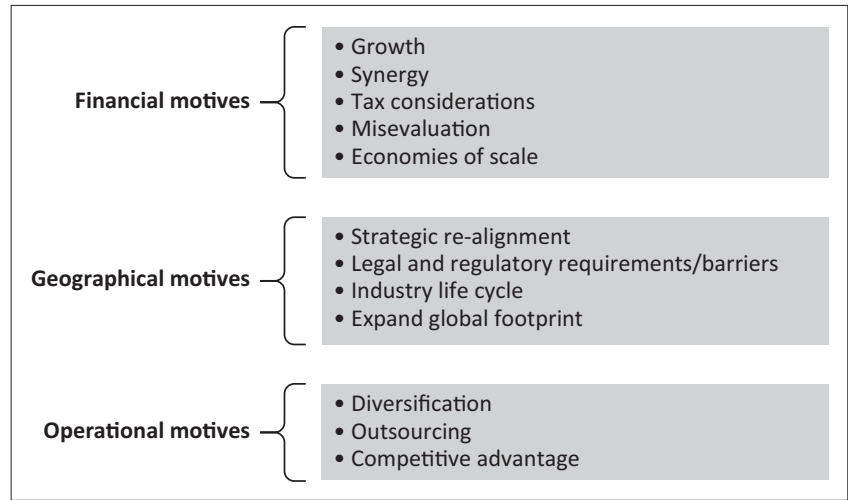

FIGURE 1: Common motivations behind mergers and acquisition activity. 
The most important aspects to consider when assessing M\&As are summarised in Table 1 below. The most important factors given by the existing literature are whether companies are publicly listed, market capitalisation, the location of the origin or source country and the destination country, the industry and sectors involved, the type of deal, whether it is a merger or acquisition, the value of the deal in US\$ and, where possible, the motives for the deal. The latter is of course the rationale for the current study.

Freight and logistics companies view inorganic growth as an imperative part to achieve their aggressive financial growth targets, improve their margins, and grow their global footprint (Dier et al. 2012; Shimizu et al. 2004). Inorganic growth offers three approaches to choose from, that is, M\&As, joint ventures or strategic alliances (Dier et al. 2012). Even though joint ventures and strategic alliances are solid options in uncertain economic times, it seems that M\&A activity in the freight and logistics industry keeps growing (Dhliwayo 2017). Industrialisation might play a large part in the latter (Rahim et al. 2013).

As could be derived here, very little literature exists regarding the specific topic of the drivers and motivations of crossborder M\&As concerning South Africa and even less for the rest of Africa. This indicates a gap in the literature and merits

\begin{tabular}{|c|c|c|}
\hline Variable & Variable name & Description \\
\hline PLC & $\begin{array}{l}\text { Publicly listed } \\
\text { companies }\end{array}$ & $\begin{array}{l}\text { The companies should be publicly listed to get wide- } \\
\text { ranging, detailed and specific information about each } \\
\text { of the companies involved in the deal and also on the } \\
\text { deal itself. }\end{array}$ \\
\hline DT & $\begin{array}{l}\text { Deal type: } \\
\text { Merger or } \\
\text { acquisition }\end{array}$ & $\begin{array}{l}\text { There are various inorganic growth deal options, but to } \\
\text { make the data more specific to the study, mergers and } \\
\text { acquisitions were identified as the only two options to } \\
\text { include. }\end{array}$ \\
\hline DV (US\$) & $\begin{array}{l}\text { Deal value in } \\
\text { US\$ }\end{array}$ & $\begin{array}{l}\text { By choosing the deals with the highest monetary value, } \\
\text { it provided the study with a sense of the size of this } \\
\text { phenomenon. }\end{array}$ \\
\hline MC & $\begin{array}{l}\text { Market } \\
\text { capitalisation }\end{array}$ & $\begin{array}{l}\text { One company was chosen in the large capital base } \\
(\$ 10 \mathrm{bn}+) \text {, one in medium cap }(\$ 2-10 \mathrm{bn}) \text { and one in } \\
\text { the small cap category (less than } \$ 2 \mathrm{bn}) \text {. Market } \\
\text { capitalisation is the aggregate valuation of the company } \\
\text { based on its current share price and the total number } \\
\text { of outstanding stocks. Market capitalisation can be } \\
\text { calculated based on whether a company has } 22 \text { million } \\
\text { shares outstanding and each share has a market value } \\
\text { of } \$ 100 ; \text { the market capitalisation of the company will } \\
\text { be } \$ 2.2 \mathrm{bn}(22000000 \times \$ 100 \text { per share). }\end{array}$ \\
\hline $\mathrm{O} / \mathrm{SC}$ & $\begin{array}{l}\text { Origin or source } \\
\text { country }\end{array}$ & $\begin{array}{l}\text { The acquiring company may be located anywhere in } \\
\text { Africa. From the data, the source country, and the name } \\
\text { of the acquiring company, should be clearly identified. } \\
\text { The acquiring company could be from anywhere in the } \\
\text { world except Africa, as this cross-border investigation } \\
\text { studies why companies outside Africa choose to } \\
\text { specifically merge with or acquire a freight and logistics } \\
\text { company in South Africa. }\end{array}$ \\
\hline DC & $\begin{array}{l}\text { Destination } \\
\text { country }\end{array}$ & $\begin{array}{l}\text { The destination country should be South Africa. It is } \\
\text { clear from the previous chapters of this study that } \\
\text { gaining a footprint into Africa is one of the main driving } \\
\text { forces behind the rationale of companies from other } \\
\text { countries merging with or acquiring a South African } \\
\text { freight and logistics company that already has networks } \\
\text { or branches in other parts of Africa. There are, } \\
\text { however, many other suggested reasons and this will } \\
\text { help to identify the main driving forces. }\end{array}$ \\
\hline $1 / \mathrm{S}$ & Industry & $\begin{array}{l}\text { Even though freight and logistics represent a wide } \\
\text { spectrum, it is not constricted to a more detailed, } \\
\text { smaller, specific sample. }\end{array}$ \\
\hline$C D$ & $\begin{array}{l}\text { Motives for the } \\
\text { deal }\end{array}$ & $\begin{array}{l}\text { From all the sources, the data have to include a } \\
\text { comprehensive, wide-ranging description of the motives } \\
\text { for the deal, as this is what the aim of the study is. This } \\
\text { will be compared to the survey's responses and } \\
\text { analysed to determine the final results and conclusions. }\end{array}$ \\
\hline
\end{tabular}

motivation for the current study. In the next section, trends on M\&As in the freight and logistics industry globally will be considered.

\section{Global trends in mergers and acquisitions in the freight and logistics industry}

The increasing use of inorganic growth methods such as M\&As in the freight and logistics industry highlights the importance of providing services to stimulate high trade, development and global income (Dhliwayo 2017; Tao et al. 2017). Services, along with strong and efficient infrastructure, are essential for a prosperous economy (Tao 2017). This section will examine specific aspects of a cross-border trade.

The transport and logistics industry showed strong performance during 2011 and 2012 globally with regard to cross-border M\&A activity (Feito-Ruiz \& Menéndez-Requejo 2011). In 2012, PwC reported the following cross-border M\&A deal activity by continent:

5 North America deals valued at $\$ 7.8$ billion; 11 European deals valued at $\$ 10.8$ billion; 8 South America deals valued at $\$ 9.4$ billion; 3 Africa deals valued at $\$ 0.3$ billion; and 13 Asia and Oceania deals valued at $\$ 2.8$ billion. (Berman 2012)

There have been two distinct waves in the value and volume of cross-border M\&As globally from 1985 to 2013, as shown in Figure 2.

The years 2000 and 2007 showed peaks in both volume and value. During 2000, approximately 40000 global transactions took place with a combined value of US\$ 4 trillion, and in 2007, approximately 48000 global transactions took place with an approximate value of US\$ 5 trillion (IMAA 2015). The financial crisis of 2008 led to a decline in M\&As globally with only approximately 39000 deals to the value of US\$ 2.5 trillion. In 2009, the value and number of deals decreased even more, but increased again in 2010 and 2011, but 2012 and 2013 again showed a slight decrease, which probably followed global economic trends (IMAA 2015).

These volumes and values highlight the importance of M\&As, where $65 \%$ of the total cross-border M\&A activity comes from the services sector. This shows that even though services were mostly neglected by international economists due to its intangible nature and therefore assumed nontradable, the sector plays an essential role in the global economy (Dhliwayo 2017; Hoekman \& Braga 1997).

M\&As have become the most prevailing form of inorganic growth methods (Das \& Kapil 2015). Companies are looking for cheaper and faster modes of entry into new markets to improve their financial, economic and geographical situations, and that is exactly what M\&As offer them. Waiting for normal organic growth takes too long, and M\&As offer much faster results while profits and a sustained income stream can be reached much faster. The potential of synergies and economies of scale is another benefit that M\&As offer companies. M\&As can also be used to obtain tax benefits and higher market power (Dier et al. 2012; Tao et al. 2017). 


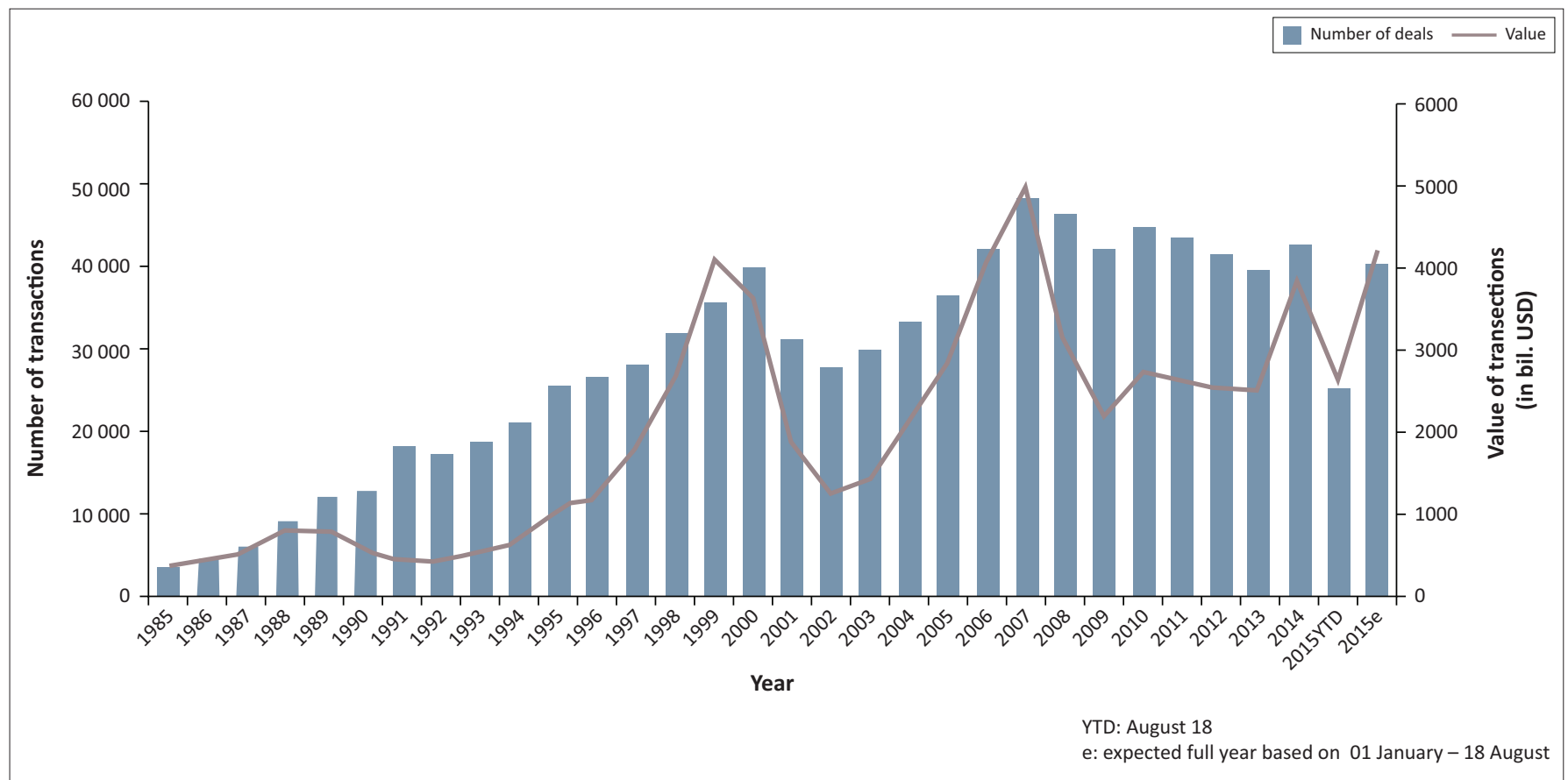

Source: Institute of Mergers, Acquisitions and Alliances (IMAA), 2015, Data and information, IMMA, New York, viewed n.d., from https://imaa-institute.org/ FIGURE 2: Global cross-border mergers and acquisition trends 1985-2015.

A specific M\&A case is FedEx, which is headquartered in Memphis, Tennessee, United States, which announced on 07 April 2015 that it is in the process of acquiring the shares of TNT Express NV, which is based in Hoofddorp, in The Netherlands, in an all-cash transaction. According to the companies, the deal is expected to increase FedEx's European capabilities and increase growth worldwide.

\section{Some examples of mergers and acquisitions in Africa and specifically South Africa}

The African population is expected to grow from approximately 1 billion in 2017 to 2 billion by 2050 (UN 2015). M\&A activity is also presumed to rise significantly over the same period (UN 2015). Since 2011, there were a few major M\&As from global companies on the African continent (KPMG 2016). Walmart, which is the 14th largest company globally by market capitalisation, wanted to gain a footprint in Africa; so, they bought a 51\% stake in Massmart Limited for an estimated R16 billion (Bezuidenhout \& Kleynhans 2015; KPMG 2016). Another example is the $100 \%$ acquisition of Dimension Data PLC by Nippon Telegraph and Telephone (NTT) Corporation of Japan. Nippon Telegraph and Telephone paid $£ 2.1 \mathrm{bn}$ for this deal, gaining them access to one of the fasted emerging markets with a growing market for new information technology (IT) and infrastructure (Reuters 2010).

Between 2009 and 2010, South Africa's M\&A activity grew by 133\% (Bam et al. 2011). Data from Reuters (2010) showed a large increase in M\&A activity in Africa. At the end of 2010, it had reached a record high of US\$ 53bn, which was $69 \%$ higher than in 2008. This shows the growing popularity of M\&As. This is also true in the South African freight and logistics industry. For example, in June 2012, C Steinweg Handelsveem B.V., based in Rotterdam in The Netherlands, acquired the majority shareholding in Bridge Shipping (Pty) Ltd, which is a South African-based company. According to the companies, the synergy between Bridge Shipping and C Steinweg allowed them to provide the best-practice, tailored, total package freight and logistics solutions to their clients, making them stronger and more competitive globally.

On 09 October 2015, DSV, a global freight and logistics company with headquarters in Hedehusene (near Copenhagen), Denmark, signed an agreement to acquire the California-based freight and logistics company, UTI. The company was originally established in South Africa, moved offshore, and then acquired by the foreign European company DSV. According to the two companies' boards of directors,

The combined company will be one of the world's strongest transport and logistics networks, and will be able to capitalise on business synergies as well as a greater global reach to the benefit of shareholders, customers and employees. (DSV 2015)

In March 2011, Aquarius Shipping International (Pty) Ltd, which is based in South Africa, joined the CWT Group, which is headquartered in Tanjong Penjuru, Singapore, through a friendly acquisition. CWT bought Aquarius to further expand and strengthen the group's commodity logistics business in Southern and Eastern Africa, to escalate the business growth and to expand related value-added services in the African continent.

Berco Express, a freight and logistics provider, was established in South Africa in 1992 and was acquired by a publicly traded freight and logistics company, Aramex, which is based in 
Dubai, United Arab Emirates, in December 2011. The aim of the transaction was to expand their global network and geographical reach into high potential, least-penetrated countries and economies.

The above-mentioned M\&As in the freight and logistics industry are only a few examples of the transactions that have taken place in recent years concerning South Africa, and it seems that most were driven by a desire by strategic investors to expand their geographical reach and improve efficiencies through inorganic growth approaches (Tao et al. 2017). However, there may be more behind these M\&As. The following section will investigate some of the reasons and/or influences of inorganic growth strategies.

The next section will explain the methodology and research design of the current study.

\section{Research design and methodology}

This section explains the theoretical and philosophical assumptions that led to the choice of the appropriate research methodology underlying this study. The aim of research is to constitute valid research in the generation of knowledge, and appropriate methods should therefore be properly justified.
In conducting research, it is essential to determine what the assumptions are on which the research is founded. For that reason, this study makes use of the 'research onion' to explain the theoretical and philosophical assumptions and determine the appropriate research design that would support this study.

Saunders et al. (2009) created the 'research onion' illustrated in Figure 3. It is a figurative concept used to guide and address the methodological objectives of the study. In every layer of the figurative research onion, there are various methodological choices that gradually help build a complete strategy and develop a set of techniques based on a theoretical approach and practical considerations. This is a helpful tool when planning a research study, as it offers a summary of important issues and considerations.

Figure 4 reflects the research design of this study. It displays each chosen option from each of the six layers or stages shown in Figure 3. The first stage dealt with various philosophies and theories and revealed the vision, considerations and assumptions of what can be classified as acceptable knowledge, applying the interpretivist approach.

Stage 2 deals with two approaches, and here the inductive approach was chosen as it links well with the interpretivism

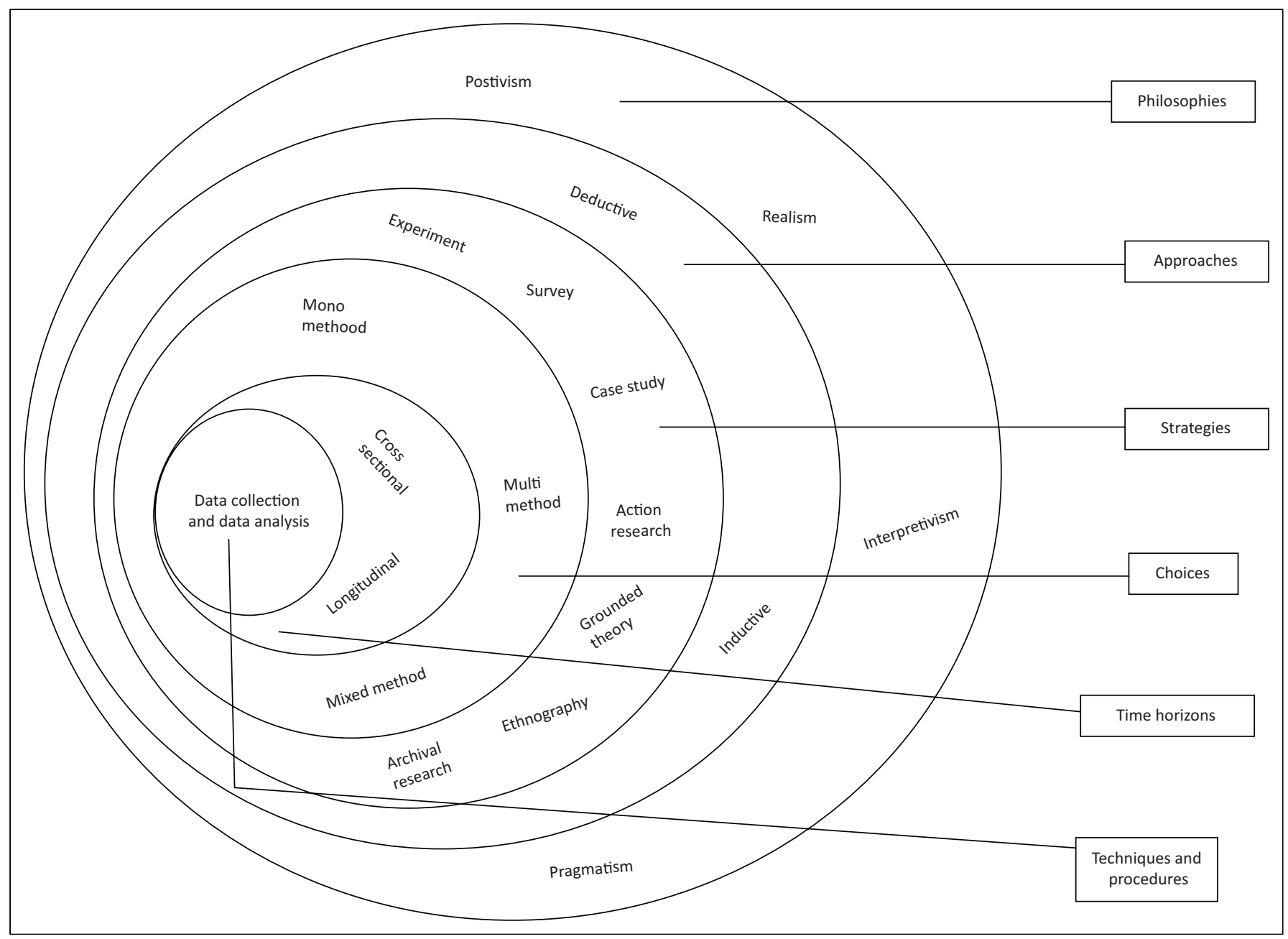

Source: Saunders, M., Lewis, P. \& Thornhill, A., 2009, Research methods for business students, 5th edn., Prentice Hall, New York

FIGURE 3: Research onion. 


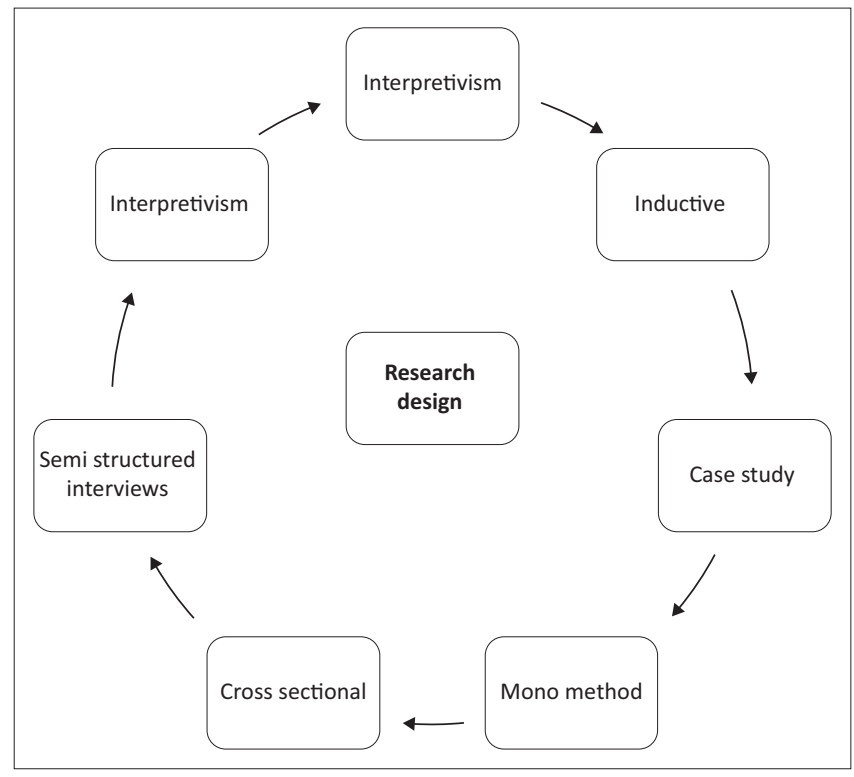

FIGURE 4: Research design of the study.

philosophy and theory. The inductive approach is mainly used in social sciences and is known to provide an alternative approach that is more flexible, and therefore it is considered to be a good option for the current study.

In the third stage, various strategies were considered. Following the chosen philosophy, theory and inductive approach, the case study strategy was chosen as it seems most suited for the scope of this study (Creswell \& Creswell 2018). Qualitative methods and especially a case study strategy are most suited as it provides the opportunity to ask 'why?', 'what?' and 'how?' questions, which will provide more context to complex M\&A matters (Marks \& Yardley 2004).

In stage 4, the mono-method as qualitative research method was followed. This allowed the interviewees to explain and elaborate on their responses, thereby providing a more profound understanding of the meanings of 'what', 'how', and why' questions (Burnard et al. 2008). There have been many critics against this method, but what qualitative analysis lacks in reliability, it makes up for in validity, because it provides a broader, richer and deeper depiction than statistical methods do (Creswell \& Creswell 2018; Russell 1996).

Qualitative research is exploratory and open-ended and focuses mainly on collecting, analysing, and interpreting data by observing what people do and say (Creswell \& Creswell 2018; Tesch 1990). With this method, it is possible to obtain the required information by exploring the participants' responses, opinions, perceptions and feelings about topics. The interviewees also gave experienced answers to the questions with regard to their specific field of expertise.

Stage 5 considers the various time horizons. Longitudinal and cross-sectional refer to the research and time horizons or timeframes of the study (Pope et al. 2006). As there were time constraints on the completion of this study, cross-sectional research was the best option.

This was mainly a mono-method study making use of questionnaires and interviews. The unit of analysis and the investigation were a South African affiliate that was acquired by an international company. After publishing the data, financial statements and reports of the various companies were studied, the researchers had a clear view of these companies and were well prepared to commence with the qualitative focus of the study. Mono-method studies have also been used by Brookhart and Durkin, (2003) and Lai and Waltman (2008) in various educational assessments.

In the final stage (Stage 6), the appropriate data collection method was chosen, while the questionnaires and interviews provided in-depth insights into participant attitudes, thoughts and actions (Kendall 2008). Interviews were used as the primary data collection tool because they will offer a better comprehension of the specific topic, allowing for theories to be proposed and generic conclusions to be formed. Additionally, qualitative open-ended questions helped tailor the process according to the context, providing a level of complexity and understanding of a specific topic (Creswell \& Creswell 2018; Miles \& Huberman 1994).

Various alternative methods could have been applied in the study, such as the resource dependence theory used by Deng and Yang (2015), or panel data analysis, event study and regression analysis (Rahim et al. 2013) to name a few, but regressions, for example, would be inappropriate as it would not answer the particular research questions, especially with regard to inorganic growth, and there were not enough M\&A companies of freight and logistics companies at that time. The most appropriate methodology was to assume the OLI theory as a basis (Shimizu et al. 2004) and to visit the relevant companies and ask them directly in well-designed case study interviews. The following sections aim to describe how the methods were approached, applied and analysed.

\section{Data, questionnaire and interviews}

According to Voss et al. (2002), depending on what the research objectives of a study and the specific issues are, a study may consist of one case study or multiple case studies; there is no set number of cases that need to be studied in this type of method. However, Eisenhardt (1989) and Remenyi et al. (1998) recommend using 3-10 cases. Eisenhardt (1989) and Yin (1994) suggest that selecting the number of cases would be based on either sampling or replication logic.

Qualitative studies always have some measure of subjectivity built into it. Some researchers regard it as a major advantage of such studies. Much effort was, however, built in to ensure the trustworthiness of the current study. Studying the hard evidence available in the published data and financial statements served as the first measure to cross-reference the information. 
For the current study, companies were chosen based on a set of criteria as the first phase of the research. Using valid, reliable and quality data is vital for this research study to ensure trustworthiness of the results, and therefore databases such as Bureau van Dijk's Zephyr and FDI markets were used to collect the data. Furthermore, a structured questionnaire was designed using the UNIDO African Union Investors survey, the World Bank Doing Business reports and the Columbia Centre for Sustainable Global Players' project surveys.

In this exploratory study, the interviews were the second phase of the primary data collection. The questions were structured and open-ended, and interviewees (respondents) were encouraged to discuss their financial, geographical and other motives, mode of entry, challenges, prospects and the underlying reasons for their choices. Some questions were also set to double check the answers and motives of respondents, which further ensured the trustworthiness of the research results obtained.

Both the questionnaire and the interviews were formulated in a way that firstly built an overview of each of the companies' business activities, the size of the company compared to domestic competitors, the geographic reach, and the company's growth over the last few years; and secondly, to gather more information about the specific mergers or acquisitions that occurred. Questions regarding the type of deal, deal structure, motivating drivers of the deal, and whether the deal was thought to be successful or not were also included. The participants also provided their views on the current and future status of the freight and logistics industry, specifically pertaining to the growth spurt of M\&As to South Africa and Africa as a whole but also to the global freight and logistics industry. It places a focus on where, when, why and how the deal happened. Their diverse perspectives provide additional value to their responses and enrich the in-depth investigation carried out by the present work.

\section{Application of the criteria}

This study is the first exploratory investigation on the determinants driving inorganic growth through M\&As in the freight and logistics industry of South Africa. The target population is freight and logistics companies globally that have carried out M\&A activities in South Africa over the past 15 years. The information chosen from the interviews and databases provide the opportunity to generalise it to theory rather than to offer statistical interpretations. The following sections will provide a structured explanation of mixed methods and especially the case design. How the number of cases were chosen, the sampling technique, inclusion criteria, and why specifically those were chosen will be revealed. The following section will provide a deeper understanding as to why a certain sample was chosen and classified as appropriate.

The objective of this sampling technique was to be able to conduct an in-depth analysis of specific case studies through detailed explanations and elaborations of interviewees on specific aspects regarding the merger or acquisition transaction. All the interviewees had knowledge of the merger or acquisition transactions, as well as extensive corporate strategy experience, which confirms that relevant, qualitative data were gathered, which also confirmed the trustworthiness of the research results.

The data gathered and other specific variables identified in the literature study were applied in Excel by means of pivot tables to identify the three major deals for this study. These specific variables are summarised in Table 1 . The table indicates the most important aspects revealed in the existing literature and theory, and it formed the basis for the case studies conducted.

\section{Application of the criteria}

After applying the identified criteria to Bureau van Dijk's Zephyr and FDI market databases, a great deal of data were retrieved and converted by means of pivot tables to narrow it down to the top 10 (acquiring and target) companies, as provided in Table 2.

The top 10 companies identified were those that adhered closest to the criteria. Out of these top companies, the data were narrowed down further to find the top five that met all of the set criteria precisely. These five companies (acquiring and target) coincided with the first five companies provided in Table 2.

The target companies were interviewed first as they are situated in South Africa. Each target company was obligated to contact their acquiring company to approve their participation in the study. Of these five identified companies, four eventually agreed to participate in the study. These companies are listed in Table 3. All the companies interviewed gave clear and written consent to being named in this article.

TABLE 2: Top 10 identified (acquiring and target) companies.

\begin{tabular}{lll}
\hline Number & Acquiring company & Target company \\
\hline 1 & CWT Limited & Aquarius Shipping International (Pty) Ltd \\
2 & Agility Logistics & Super Group Ltd \\
3 & DSV & UTI \\
4 & ARAMEX & Berco Express \\
5 & Glencore, Pacorini & Access Freight \\
6 & Dachser Gmbh and Co Kg & Jonen Freight Pty Ltd \\
7 & KAP International & PG Bison Holdings (Pty) Ltd \\
8 & Lonrho PLC & Grindrod Perishable Cargo Agents Pty Ltd \\
9 & BALtrans Holdings Ltd & Clover Cargo Holdings (Proprietary) Ltd \\
10 & Tibbett and Britten Group PLC & Kinesis Logistics \\
\hline
\end{tabular}

TABLE 3: The four participating companies (acquiring and target).

\begin{tabular}{lll}
\hline Number & Acquiring company & Target company \\
\hline 1 & DSV & UTI \\
2 & Glencore, Pacorini & Access Freight \\
3 & CWT & Aquarius \\
4 & Aramex & Berco Express \\
\hline
\end{tabular}


The questionnaires were sent to the target companies, which completed it in collaboration with their acquirers, after which interviews were conducted.

The DSV-UTI deal was still very new at the time, and after the questionnaires and interviews were conducted with senior personnel, the authors decided not to include this deal in the article, as the results were still inconclusive. The deal would result in retrenchments, and the personnel were very emotional and biased with regard to their responses to questions about the acquisition at the time of the study.

\section{Ethical consideration}

An ethical clearance was obtained by the Ethics Committee of North-West University (2013 \& 2019). NWU Ethical Clearance no: Fakulteit-06/11/2013. The subject matter research was not of a sensitive matter, although treated as confidential.

\section{Empirical findings}

The results that were gathered using questionnaires and interviews from freight and logistics MNEs are interpreted and discussed in this section. The results portray the drivers behind the inorganic growth methods that motivated M\&As in the freight and logistics industry. A cross-case analysis of the three acquisitions below will also indicate how each case compares to the other. As this study is an interview-based case study, it can only serve as a benchmark. The focus is on the factual company experience and can therefore not be generalised industry wide. This might be regarded as a limitation of the study, although the authors disagree as it does contribute some knowledge to the current knowledge base.

\section{Summary of findings from the three case studies}

In this section, brief summaries of the companies investigated are provided, which include, among others, the history of the companies, the industries they operate in, the areas or geographic locations they conduct business in, services and/ or products they specialise in and details about the merger deals. It will also discuss some of the main results from each case study. Hereafter, the companies will be referred to as 'Glencore', 'Pacorini' and 'Access'.

\section{Glencore International PLC - Pacorini Metals Europe (B.V.) - Access Freight Group (Pty) Ltd.}

Glencore International PLC, which is an acronym for 'Global Energy Commodity Resources', was founded in 1974 with its headquarters in Baar, Switzerland. Glencore is a wellknown, established and diversified vertically integrated producer, processor and trader of various commodities to several industries globally. Glencore's three business segments are: metals and minerals, energy products and agricultural products, as well as marketing and logistics. Their scale and diversity make them a reliable, competitive multinational company with a presence at every stage of the commodity chain.

During 2010, Glencore International PLC acquired the Pacorini Metals Warehousing division of the Pacorini Group for an estimated amount of $\$ 209$ million. The metals division was to continue to operate under the name Pacorini Metals Europe (B.V.). In 2013, this division of Pacorini announced its intentions to venture into the African continent, and acquired a sub-Saharan warehousing business from the South African logistics group Access Freight Group (Pty) Ltd. The deal allowed them to profit from the growing production of metals and minerals, including copper, cobalt and iron ore in this region. This is in accordance with the resource-seeking objective highlighted by the OLI theory above (Bezuidenhout \& Kleynhans 2018).

The results from the questionnaires and interviews with Access Freight Group indicate that a variety of motives drove the acquisition of Access Freight by Pacorini. They focused mainly on the efficiency and strategic motives set by the OLI theory. These motives were Pacorini's aim of achieving fast and high levels of growth and expansion into the African market, achieving production economies of scale and benefiting from operation, financial and managerial synergies, to gain a competitive advantage in the market, and to make economic profits applying the factors of production, which include land, labour, capital and entrepreneurship. This also agrees with the research of Tao et al. (2017) conducted on Chinese FDI through M\&As.

The respondents mentioned that this form of acquisition was effective because the acquirer was buying an existing revenue stream, skills, knowledge and competencies and, at the same time, speeding up the process of establishing a presence in the target market. This strategy was viewed as less risky than establishing their own presence in the market.

Access Freight Group's main domestic competitors were also acquired before Pacorini made an offer to the company, which left it in a vulnerable position where they had to consider their own competitive position. The two companies' culture and future goals were well aligned and therefore made it an attractive situation for both parties (Rohlfer \& Zhang 2016).

Overall, the results of this acquisition deal were positive for both companies involved, and Pacorini gained a footprint in Africa, and access to valuable resources, skills and knowledge within Access Freight; in turn, Access Freight also gained a stronger competitive position in the market.

\section{CWT Group - Aquarius Shipping International}

The CWT Group is a well-known, leading provider of integrated logistics globally. The company was founded in 1970, with its headquarters in Singapore, and in 2014, the company reported a revenue of $\$ 15.2 \mathrm{bn}$. The company has 
been listed on the Singapore Exchange since 1993 and is known as the largest listed logistics company in Southeast Asia. The CWT Group serves the logistical needs of clients in various industries.

Aquarius Shipping International (ASI) is a freight and logistics company in Africa, with its headquarters in Durban. ASI had built a solid reputation in the domestic freight and logistics industry and, in recent years, also established offices in Malawi, Zimbabwe, Zambia and Mozambique. It offers shipping, warehousing, customs clearance and other forwarding services to its clients.

In November 2010, the CWT Group announced that it had officially signed a conditional sale and purchase agreement whereby they would acquire a $60 \%$ share in ASI through the CWT Europe arm of its wholly owned subsidiary, CWT Commodities. The company states that the main reason for the acquisition was to strengthen its commodity logistics capabilities and business network in Southern and Eastern Africa, which corresponds to the market-seeking objective set by the OLI theory.

Many motives were listed by both companies for the acquisition during our case study analysis, including efficiency-seeking, growth, economies of scale and developing their competitive advantage. Again, as in the previous case study, the acquirer's main aim was to establish an African footprint, and the ASI motivation was uncertainty, as many domestic competitors were also being targeted and eventually acquired by other multinational companies. This led them to doubt their ability to compete effectively in the region in future.

The respondent mentioned that even though the main decision and offer to acquire ASI came from CWT, the benefits were a two-way deal. ASI was considering factors such as when the best time would be to sell the company, for how much to sell the company, who to sell the company to and weighing the opportunity cost between organic and inorganic growth methods. At the same time, CWT was looking to grow into the African continent and was looking for a freight and logistics company in South Africa that had a well-known brand, well-developed freight and logistics services, a strong competitive position in the market, and who was willing to sell. According to the respondent, CWT was looking for a company that had experience and knowledge of the African continent, including infrastructural, economic, political and business cultures, to become a part of their team. They believed that it was the best method for fast and vast growth.

CWT gained access to ASI's network and infrastructure such as warehousing and storage space, which was a huge gain for CWT as they own similar facilities in eight countries globally. The respondent indicated that, in terms of operational synergy, the two companies both gained in terms of margins and growth. ASI gained higher revenues, increased debt capacity, a moderate decrease in operational cost, and a lower cost of capital. CWT gained a decrease in operational cost, tax benefits, higher revenues and a lower cost of capital. However, there were several negative issues raised by the respondent.

ASI did not receive any reduction in operational cost as was expected by its efficiency-seeking motive, and CWT had hoped to receive a high level of revenue return over a short period of time. CWT was also not prepared for the higher levels of risk it faces when doing business in Africa, and therefore committed to reviewing their risk management strategies to accommodate the local context. ASI's local management team also recognised that they were not sufficiently prepared for the cultural differences between the South African team and CWT's team from Singapore, and this made the negotiation phase of the deal complex. Understanding the cultural dynamics is essential to ensure successful negotiations, especially within a diverse cultural realm (Rohlfer \& Zhang 2016). More preparation should have been done from their side to understand the cultural differences and negotiation approaches. The OLI theory emphasises the importance of the strategy-seeking motive and this company clearly neglected this part of the business (Tao et al. 2017).

\section{Aramex-Berco Express acquisition}

Aramex is a leading global provider of transportation and logistics services. The company was established in 1982 as an express operator and has since expanded to 354 locations globally. Aramex was the first Arab-based international company to trade shares on the NASDAQ stock exchange in 1997. They offer various freight-forwarding services, domestic and international express delivery, warehousing and logistics functions.

Berco Express is a courier, warehousing and logistics company based in South Africa. It was founded in 1992 and has 15 branches in South Africa. They were still a relatively small company compared to their competitors before the acquisition.

In December 2011, it was announced that Aramex would acquire a $100 \%$ stake of Berco Express. The acquisition was claimed to form part of its long-term expansion strategy to strengthen their presence in emerging markets, which gave them the locational advantages highlighted by the OLI theory. Tao et al. (2017) found similar results studying Chinese companies. Aramex also viewed South Africa as a highly attractive market with a business-friendly environment and significant growth prospects. They stated that Berco Express is a company with good management and a leading branch in the region and would contribute to their expansion plans for the African region. Due to the recent increase in M\&As in South Africa's logistics industry, Berco Express found themselves under pressure to either expand, or face the challenge of increasing international competition. Both 
companies, therefore, viewed this deal as a potential driver for growth, economies of scale, synergy between their operations, and gaining a competitive advantage.

\section{Motives for the acquisition - Cross-case analysis}

The resulting driving forces that motivated the specific M\&As of the companies researched in this study are discussed in this section. The primary data gathered on these motives for the acquisition have been analysed against the theory and literature discussed in previous sections. The findings are summarised in Tables 4 and 5.

Table 4 illustrates that the three deals were all motivated by the same macro-economic factors creating acquisition motives, namely merger waves (a dramatic increase in M\&As in the local industry), changes in the economic environment, technological progression and financial shocks. Changes in the economic environment led to more M\&As. All foreign investors viewed the domestic political situation as a negative factor, thereby potentially decreasing their willingness to invest in the local market. This affected their risk-taking strategies directly. However, despite this factor, the other motives were sufficient to go ahead.

Table 5 compares the various micro-level or company-level motives of each of the three deals investigated.

After comparing the results of the cases investigated with each other in Table 5, it can be concluded that growth, economies of scale, synergies, competitive advantage and exploiting an opportunity that arose were the most significant motivations and driving forces behind MNEs choosing to pursue inorganic growth methods through M\&As.

What was learned from these case studies was that these types of M\&As in the logistics industry in South Africa were driven by a mutual drive by both the acquirer and acquired company to find opportunities for further growth and expansion through the deals. In each case, both parties viewed the deal as a way to gain further competitive advantage, and international companies were all motivated by the drive to gain market access into South Africa and the African continent. This is also in line with the focus on OLI set by the OLI theory and the resource, market, efficiency and strategic motives of companies (Deng \& Yang 2015). They, therefore, searched for strong, established South African companies with a foothold in the region.

The South African companies are all looking for opportunities to increase their competitive advantage and expand their operations by gaining knowledge, technology and expertise from the foreign companies (Tao et al. 2017). What was interesting to note from the CWT-ASI case study was that the South African companies were ill equipped and unprepared for negotiations within a diverse cultural realm and viewed the cultural differences as a problem in the negotiation stage.
TABLE 4: Macro-economic factors determining acquisition motives.

\begin{tabular}{|c|c|c|c|}
\hline \multirow[t]{2}{*}{ Theory } & $\begin{array}{c}\text { Empirical data: } \\
\text { verifies or falsifies } \\
\text { theory } \\
\end{array}$ & $\begin{array}{c}\text { Empirical data: } \\
\text { verifies or falsifies } \\
\text { theory } \\
\end{array}$ & $\begin{array}{c}\text { Empirical data: } \\
\text { verifies or falsifies } \\
\text { theory }\end{array}$ \\
\hline & Pacorini-Access & CWT-ASI & Aramex-Berco \\
\hline Merger waves & + & + & + \\
\hline Political decisions & - & - & - \\
\hline $\begin{array}{l}\text { Changes in economic } \\
\text { environment }\end{array}$ & + & + & + \\
\hline $\begin{array}{l}\text { Technological } \\
\text { progression }\end{array}$ & - & - & - \\
\hline Financial shocks & + & + & + \\
\hline
\end{tabular}

Note: + , data fit or agree with/ support the theory. -, data do not fit or agree with or support the theory.

TABLE 5: Motives for the acquisition.

\begin{tabular}{|c|c|c|c|}
\hline \multirow[t]{2}{*}{ Theory } & $\begin{array}{c}\text { Empirical data: } \\
\text { verifies or falsifies } \\
\text { theory }\end{array}$ & $\begin{array}{c}\text { Empirical data: } \\
\text { verifies or falsifies } \\
\text { theory }\end{array}$ & $\begin{array}{c}\text { Empirical data: } \\
\text { verifies or falsifies } \\
\text { theory }\end{array}$ \\
\hline & Pacorini-Access & CWT-ASI & Aramex-Berco \\
\hline
\end{tabular}

\begin{tabular}{llll}
\hline Growth & + & + & + \\
Economies of scale & + & + & + \\
Transaction costs & - & + & - \\
Diversification & - & - & - \\
Debt or equity & - & - & - \\
Monopoly & - & - & - \\
Undervaluation & - & - & - \\
Synergy & + & + & + \\
Empire building & - & - & - \\
Access to capital & - & - & - \\
markets & + & + & + \\
Competitive advantage & + & - & - \\
Tax and incentives & - & - & - \\
Factors of production & - & - & - \\
Improving product & - & + & + \\
portfolio & & & \\
Exploit opportunity & + & - & \\
\hline
\end{tabular}

Note: + , considered to be a motive for the acquisition. -, not considered to be a motive for the acquisition.

The following section concludes this study and elaborates on the findings revealed by the empirical analysis of this investigation.

\section{Summary and conclusion}

The objectives of this study were to determine the drivers of inorganic growth through M\&As in the freight and logistics industry of South Africa by adopting a process perspective. In essence, this study attempted to determine why large MNEs are using inorganic growth methods rather than normal organic growth methods of development and profit generation. The research systematically investigated and discovered evidence about the reasons why large MNEs in the services and transport sector are specifically focusing on M\&As as their major inorganic growth method and also to identify why these MNEs are specifically targeting the African continent.

From theory and the literature review and the analysis of the findings, the most significant conclusion is that the main driving force behind M\&As is growth, which includes growth in size, geographical reach, growth into new markets and economies, growth in revenue, profits or assets, as well as fast growth (Narayan \& Thenmozhi 2014). Other driving 
forces include economies of scale, synergy, transaction costs, competitive advantage and exploiting an opportunity that arose.

Multinational enterprises in the freight and logistics industry choose inorganic growth methods rather than ordinary growth methods because they immediately expand their assets, income and market presence. It provides access to a new customer base and adds new geographical locations. Time-to-market is substantially reduced leading to a significant competitive edge. It provides a stronger line of credit because of the combined value of the two businesses. There is also a possibility to achieve economies of scale over a relatively short period of time. M\&As help reduce competition in the market place, and instantly add new brands and product and service lines to the acquiring company.

Africa and other emerging markets are becoming more and more attractive to MNEs because they offer sustained high rates of growth and return on investments. They are not affected by financial crises in the same way as developed countries are due to their sound financial sector, along with the support from domestic demand and a relatively more isolated location. These economies capture more than half of the world's gross domestic product (GDP) in terms of purchasing power parity and attract in excess of $50 \%$ of the inflows of FDI.

Multinational enterprises clearly see South Africa as the gateway into Africa because South Africa has a high market potential, well-developed infrastructure, a reasonably competitive domestic economy, free-market economy, transparent regulatory framework, access to raw materials and political stability, and a large and active stock exchange. The country encourages foreign investment in both the public and private sectors. Economic reforms have led to macro-economic stability, as well as tax and customs reduction.

In further research, this investigation should be expanded to cover other industries as well and investigate M\&As where other less-developed countries in Africa and elsewhere are involved. Motives and determinants for M\&As especially in other countries differ and so do the risks involved in crossborder mergers. These differ among regions and also among various industries. Studies investigating the extent to which M\&As led to higher efficiency and profits should be ascertained, as well as their effect on job creation. The results also found that South African companies need to expand their cultural intelligence and negotiation skills, especially within a diverse cultural realm, before entering into M\&A deals with foreign companies. Further specifics in this regard merit special investigations.

The findings of this study constitute substantial contributions to an understanding of the M\&A phenomenon in the freight and logistics industry in South Africa. The study yields practical implications and is of value to managers and policymakers. Companies need expertise in M\&A processes, and this study highlighted valuable findings in that regard. Service industries are determinants of trade volumes and offer distributional effects and patterns of economic growth, development and FDI inflows. Little research exists on the dynamics of M\&As in the freight and logistics industry, especially within the African context. In that regard, this study also makes an original contribution, which should be studied further.

\section{Acknowledgements}

The authors acknowledge the support from the World Trade Organization and the National Research Foundation.

\section{Competing interests}

The authors declare no conflict of interest with regard to the writing of this article.

\section{Authors' contributions}

H.B. designed the original concept and performed most of the original empirical analysis concerning M\&As. S.G. investigated the theory and practice of the Freight and Logistics industry and processed the research results of the specific companies. J.C.D.V. conducted the literature study, conducted the interviews and compiled the original findings as part of her Master's study. E.P.J.K. assisted in the composition, analysis and evaluation and wrote the final article.

\section{Funding}

Funding for this study was obtained from the National Research Foundation and World Trade Organization.

\section{Data availability statement}

Data are available on the referenced websites and from the authors on request.

\section{Disclaimer}

The views and opinions expressed and conclusions arrived at in this article are those of the authors and should not necessarily be attributed to the funding institutions.

\section{References}

Anyanwu, J.C., 2006, 'Promoting of investment in Africa', African Development Review 18(1), 42-71.

Asafo-Adjei, A., 2007, 'Foreign Direct Investment and its Importance to the Economy of South Africa', M.Com.- Dissertation, University of South Africa, Pretoria.

Bam, E.K.P., Akiti, T.T., Osae, S.D., Ganyaglo, S.Y. \& Abass Gibrilla, A., 2011, 'Multivariate cluster analysis of some major and trace elements distribution in an unsaturated zone profile, Densu river basin, Ghana', African Journal of Environmental Science and Technology 5(3), 155-167. https://doi.org/10.4314/ajest.v5i3.71923

Berman, J., 2012, 'PwC report shows promising signs for transportation and logistics deals in 2012', SupplyChain247.com, Morganville, New Jersey, viewed n.d., from https://www.supplychain247.com/article/pwc_report_shows_promising_signs_ for_transportation_and_logistics_deals_in_/news.

Bertrand, A., 2004, 'Mergers and Acquisitions (M\&As). Greenfields Investment and extensions of capacity', Issue Papers no. 4, pp. 28-29, IMF, Washington, DC. 
Bezuidenhout, H., Grater, S. \& Kleynhans, E.P.J., 2018, 'Investigating the global value chain dimensions of FDI flows of the agro-industrial sector of South Africa', Acto Commercii 18(1), 1-13, a560. https://doi.org/10.4102/ac.v18i1.560

Bezuidenhout, H. \& Kleynhans, E.P.J., 2015, 'Implications of foreign direct investment on sovereignty: The Wal-Mart/Massmart merger as illustration', South African Journal of International Affairs 22(1), 93-110. https://doi.org/10.1080/1022046 1.2015.1009155

Bezuidenhout, H. \& Kleynhans, E.P.J., 2018, 'Modern trends in Chinese foreign direct investment in Africa: An OLI approach', Managing Global Transitions. International Research Journal 16(3), 279-300. https://doi.org/10.26493/18546935.16.279-300

Buono, A.F., 1997, 'Technology transfer through acquisition', Management Decision 35(3), 194-204. https://doi.org/10.1108/00251749710169404

Brookhart, S.M. \& Durkin, D.T., 2003, 'Classroom assessment, student motivation, and achievement in high school social studies classes', Applied Measurement in Education 16(1), 27-54. https://doi.org/10.1207/S15324818AME1601_2

Burnard, P., Craft, A., Cremin, T. \& Chappell, K., 2008, 'Developing methodology for exploring 'creative learning' and 'possibility thinking', paper presented at American Educational Research Association annual meeting, New York.

Cartwright, S. \& Schoenberg, R., 2006, 'Thirty years of mergers and acquisitions research: Recent advances and future opportunities', British Journal of Management 17(1), S1-S5. https://doi.org/10.1111/j.1467-8551.2006.00475.x

Coetzee, Z., Bezuidenhout, H., Claassen, C. \& Kleynhans, E.P.J., 2016, 'Profiling sectoral risks of foreign direct investment (FDI) in Africa for the first decade of the 21st century', Journal of Economic and Financial Sciences 9(1), 153-173.

Changqi, W. \& Ningling, X., 2010, 'Determinants of cross-border merger \& acquisition performance of Chinese enterprises', Procedia-Social and Behavioral Sciences 2(5), 6896-6905. https://doi.org/10.1016/j.sbspro.2010.05.040

Creswell, J.W. \& Creswell, J.D., 2018, Research design: Qualitative, quantitative, and mixed methods approaches, Sage, Los Angeles, CA.

DSV, 2015, 'DSV agrees to acquire UTi Worldwide Inc', DSV Global Transport and Logistics. Hedehusene, Denmark, viewed n.d., from https://www.dsv.com/AboutDSV/media/latest-news/2015/10/DSV-agrees-to-acquire-UTi-Worldwide-Inc.

Dhliwayo, S., 2017, 'Export experience and key success factors in cross-border trade: Evidence from Southern Africa', Acta Commercii 17(1), 1-9, a383. https://doi. org/10.4102/ac.v17i1.383

Das, A. \& Kapil, S., 2015, 'Inorganic growth of technology sector firms in emerging markets: Influence of firm-specific factors in Indian firms' M\&A activities', International Journal of Emerging Markets 10(1), 52-72. https://doi.org/10.1108/ IJOEM-06-2012-0057

Deng, P. \& Yang, M., 2015, 'Cross-border mergers and acquisitions by emerging market firms: A comparative investigation', International Business Review 24(1), 157-172. https://doi.org/10.1016/j.ibusrev.2014.07.005

Dier, M., Sturm, M., Junghanns, J. \& Ali, S., 2012, 'Why M\&A is the right option to capitalise on growth opportunities in the freight and logistics industry', Accenture, Boston, MA, viewed 12 October 2017, from https://www.accenture.com/.

Dunning, J.H., 1977, 'Trade, location and economic activity and the multinational enterprise: A search for an eclectic approach', in B. Ohlin, O. Hesselborn \& M. Wijkman (eds.), International allocation of economic activity, pp. 395-418, Palgrave Macmillan, London.

Dunning, J.H., 2001, 'The eclectic (OLI) paradigm of international production: Past, present and future', International Journal of the Economics of Business 8(2) 173-190. https://doi.org/10.1080/13571510110051441

Dunning, J.H. \& Lundan, S.M., 2008a, 'Institutions and the OLI paradigm of the multinational enterprise', Asia Pacific Journal of Management 25(4), 573-593.

Dunning, J.H. \& Lundan, S.M., 2008b, Multinational enterprises and the global economy, 2nd edn., Edward Elgar, Cheltenham, UK.

Dupasquier, C. \& Osakwe, P.N., 2003, 'Performance, promotion, and prospects for foreign investment in Africa: National, regional, and international responsibilities', paper prepared for the 'Eminent Persons' meeting on promotion of investment in Africa, Tokyo, February.

Eisenhardt, K.M., 1989, 'Making fast strategic decisions in high-velocity environments', Academy of Management Journal 32(3), 543-576.

Erel, I., Liao, R.C. \& Weisbach, M.S., 2012, 'Determinants of cross-border mergers and acquisitions', Journal of Finance 67(3), 1045-1082. https://doi.org/10.1111/ j.1540-6261.2012.01741.x

Feito-Ruiz, I. \& Menéndez-Requejo, S., 2011, 'Cross-border mergers and acquisition in different legal environments', International Review of Law and Economics 31(3), 169-187. https://doi.org/10.1016/j.irle.2011.05.002

Fortanier, F., 2007, 'Foreign direct investment and host country economic growth Does the investor's country of origin play a role?', Transnational Corporation 16(2), 41-76.

Harding, D., Shankar, S. \& Jackson, R., 2013, The renaissance in mergers and acquisitions: The surprising lessons of the 2000s, Bain \& Company, Boston, MA.

Hoekman, B. \& Braga, C.A.P., 1997, 'Protection and trade in services: A survey', Open Economies Review 8(3), 285-308.

Hurst, L., 2011, 'Comparative analysis of the determinants of China's state-owned outward direct investment in OECD and non-OECD countries', China \& World Economy 19(4), 74-91. https://doi.org/10.1111/j.1749-124X.2011.01251.x

Institute of Mergers, Acquisitions and Alliances (IMAA), 2015, Data and information, IMMA, New York, viewed n.d., from https://imaa-institute.org/
Kendall, L., 2008, 'The conduct of qualitative interviews: Research questions, methodological issues, and researching online', in J. Coiro, M. Knobel, C. Lankshear $\&$ D.J. Leu (eds.), Handbook of research on new literacies, pp. 133-149, Lawrence $\&$ D.J. Leu (eds.), Handbook of
Erlbaum Associates, New York.

Kimura, Y., 1989, 'Firm-specific strategic advantages and foreign direct investment behavior of firms: The case of Japanese semiconductor firms', Journal of International Business Studies 20(2), 296-314.

Kleynhans, E.P.J. \& Zwedala, S., 2012, 'The contribution of FDI, technology and R\&D to spill overs in industrial development: A South African firm-level investigation" Managing Global Transitions 10(4), 341-359.

Lai, E.R. \& Waltman, K., 2008, 'Test preparation: Examining teacher perceptions and practices', Educational Measurement: Issues and Practice 27(2), 28-45. https:// doi.org/10.1111/j.1745-3992.2008.00120.x

Malhotra, N. \& Hinings, C.R., 2010, 'An organizational model for understanding internationalization processes', Journal of International Business Studies 41(2), 330-349.

Mankiw, N.G., 2014, Principles of economics, Cengage Learning, Hampshire.

Marks, D. \& Yardley, L., 2004, Research methods for clinical and health psychology, Sage, London.

Masipa, T.S., 2018, 'The relationship between foreign direct investment and economic growth in South Africa: Vector error correction analysis', Acta Commercii 18(1), 1-8, a466. https://doi.org/10.4102/ac.v18i1.466

Meersman, H. \& Van de Voorde, E., 1999, 'Is freight transport growth inevitable?', in ECMT (ed.), Which changes for transport in the next century?, pp. 23-48, European Conference of Ministers of Transport, OECD Publications Services, Paris.

Miles, M.B. \& Huberman, A.M., 1994, Qualitative data analysis, 2nd edn., Sage, Thousand Oaks, CA.

Moeller, S. \& Brady, C., 2007, Intelligent M\&A: Navigating the Mergers and Acquisitions Minefield, Wiley, Chichester.

Narayan, P.C. \& Thenmozhi, M., 2014, 'Do cross-border acquisitions involving emerging market firms create value: Impact of deal characteristics', Management Decision 52(8), 1451-1473. https://doi.org/10.1108/MD-04-2014-0227

Newburry, W. \& Zeira, Y., 1997, 'Implications for parent companies', Journal of World Business 32(2), 87-102.

Jurevicius, O., 2013, 'Strategic management \& strategic planning', Strategic Management Insight, viewed from https://www.strategicmanagementinsight. $\mathrm{com} /$ topics/strategic-planning-process.html.

Pope, J., Annandale, D. \& Morrison-Saunders, A., 2004, 'Conceptualising sustainability assessment', Environmental Impact Assessment Review 24(6), 595-616. https:// doi.org/10.1016/j.eiar.2004.03.001

Quazi, R.M., 2007, 'Investment climate and foreign direct investment: A study of selected countries in Latin America', Global Journal of Business Research 1(1), $1-13$.

Rahim, K.F., Ahmad, N., Ahmad, I. \& Rahim, F.A., 2013, 'Determinants of cross border merger and acquisition in advanced emerging market acquiring firms', Procedia Economics and Finance 7, 96-102.

Rappaport, A., 1986, Creating shareholder value: The new standard for business performance, Free Press, New York.

Rappaport, A., 1998, Creating shareholder value: A guide for managers and investors, Free Press, New York.

Rohlfer, S. \& Zhang, Y., 2016, 'Culture studies in international business: paradigmatic shifts', European Business Review 28(1), 39-62. https://doi.org/10.1108/EBR-072015-0070

Russell, B., 1996, 'Qualitative data, quantitative analysis', Cultural Anthropology Methods Journal 8(1), 9-11.

Samitas, A.G. \& Kenourgios, D.F., 2007, 'Impact of mergers and acquisitions on stock returns of tramp shipping firms', International Journal of Financial Services Management 2(4), 327-343. https://doi.org/10.1504/IJFSM.2007.016288

Saunders, M., Lewis, P. \& Thornhill, A., 2009, Research methods for business students, 5th edn., Prentice Hall, New York.

Shimizu, K., Hitt, M.A., Vaidyanath, D. \& Pisano, V., 2004, 'Theoretical foundations of cross-border mergers and acquisitions: A review of current research and recommendations for the future', Journal of International Management 10(3) 307-353. https://doi.org/10.1016/j.intman.2004.05.005

Smith, S., 1997, 'Restrictive policy toward multinationals: Argentina and Korea', in S. Smith (ed.) Case studies in economic development, 2nd edn., pp. 178-189, Department of Economics, George Washington University, Boston, MA.

Sun, X., 2002, 'FDI and economic development: What do the states need to do?', United Nations Public Administration Network (UNPAN), Morocco, viewed 12 October 2017, from https://unpan1.un.org/intradoc/groups/public/documents/ un/unpan006348.pdf.

Tao, F., Liu, X., Gao, L. \& Xia, E., 2017, 'Do cross-border mergers and acquisitions increase short-term market performance?', The case of Chinese firms. International Business Review 26(1), 189-202. https://doi.org/10.1016/j.ibusrev.2016.06.006

Tesch, R., 1990, Qualitative research: Analysis types and software tools, Falmer Press, New York.

Yang, M., 2015, 'Ownership participation of cross-border mergers and acquisitions by emerging market firms: Antecedents and performance', Management Decision 53(1), 221-246. https://doi.org/10.1108/MD-05-2014-0260

Yin, R.K., 1994, Case study research design and methods: Applied social research and methods series, 2 nd edn., Sage, Thousand Oaks, CA. 